\title{
DIE OUDERLING EN TOESIG OOR DIE LEWE
}

Prof. J. H. van Wyk.

\section{OM TE BEGIN.}

In hierdie voordrag sal die aksent meer op lewensprobleme val. Tog sal dit nodig wees om enkele opmerkinge te maak in verband met die gedagte van "toesig hou oor" tydens huisbesoek. Met die woorde "toesig hou oor" is immers 'n beskrywing gegee van die taak van ouderlinge tydens huisbesoek en die vraag kan gestel word of hierdie woord genoeg omskrywend is. Hou dit nie 'n verenging en vereensydiging in van die taak van die ouderling nie? Of is hierdie verenging doelbewus gekies ten einde hierdie aspek skerp te belig?

\section{HUISBESOEK IS MEER AS "TOESIG HOU OOR"}

\subsection{Pastoraal-teologiese omskrywinge ${ }^{1}$}

Wanneer ons 'n vinnige en willekeurige blik werp in boeke wat oor die pastoraat geskryf is, blyk al gou dat talle definisies oorweeg is ten einde 'n verantwoorde omskrywing van die pastoraat te gee. Daar word byvoorbeeld gepraat van die "bediening van die versoening"'; van die verkondiging of bediening van die evangelie'; van die reëling van 'n ontmoeting tussen God en mens'; van kommunikasie van die evangelie of die evangelie "in actu"5; van persoonlike toepassing van die Woord $^{0}$; van paraklese as kommunikasiegebeure wat die liefdevolle gemeenskap in Christus, die dinamiese koinonia van die Gees en die sorgsame bewoënheid van die Vader bemiddel.

Dit is gou duidelik dat dit hier gaan oor die ontmoeting van God deur Jesus Christus in die krag van die Heilige Gees" en dat iemand so gelei moet word dat hy in volle gemeenskap met Christus sal lewe ${ }^{9}$. Dit trek saam in die bediening van die evangelie, met sy wesentlike komponente van bekering en vergewing (Luk 24:27), verlossing en versoening ( 11 Kor. $5: 18 \mathrm{v}$ ).

Uiteraard kom hier dan veel meer ter sprake as "toesig hou oor". Woorde soos vermaning, bemoediging, geloofsopbou en -toerusting kom dan skerp in die gesigsveld. Daar word gepraat van heling, bystand, begeleiding (tug) ${ }^{10}$, oorwinningsorg ${ }^{11}$ ensovoorts.

\subsection{Nuwe-Testamentiese omskrywinge. ${ }^{12}$}

Kyk ons na veral die Nuwe Testament dan blyk al gou dat 'n bonte verskeidenheid van woorde gebruik word om die pastorale taak van die ouderling te omskryf. Ons let vlugtig op 'n aantal daarvan en telkens verwys ek eerstens na die Ou Afrikaanse Bybelvertaling (OAV) en daarna, wanneer die vertalings verskil, na die Nuwe Afrikaanse Vertaling (NAV).

In Joh $21: 15 \mathrm{v}$ gee Jesus Christus aan Simon Petrus - en daarmee in beginsel aan alle ouderlinge (vgl 1 Pet. $5: 1$ ) - die klassieke opdrag om sy lammers te laat wei en sy skape op te pas - seker die beeldrykste en diepsinnigste omskrywing van wat pastoraat wesentlik is. Dit spreek van die broosheid en sondigheid van die kudde van Christus (lammers) én dit spreek van die sorgsaamheid (voed en 
lei) en oppassendheid (bewaar en beskerm) van die herder. Dit sluit as sodanig aan by die bekende herderbeeld van Ps. 23 en Joh. 10 .

In Hand 20:28 gee Paulus aan die ouderlinge van Efese die opdrag om "ag te gee" op die hele kudde (op te pas) en om as herders die hele gemeente van God "te versorg".

In Efes. 4:12 word as taak gestel om die heiliges "toe te rus vir hulle dienswerk", tot opbouing van die liggaam van Christus.

In 1 Tess $5: 14-15$ word ók van die voorgangers gevra om die onordelikes te vermaan (die leeglêer tereg te wys), die kleinmoediges te bemoedig, die swakkes te ondersteun (die swakkes te help), lankmoedig te wees teenoor almal (geduldig te wees met almal); verder moet gesorg word dat niemand ' $n$ ander kwaad vir kwaad vergeld nie, maar jaag altyd ná wat goed is, teenoor mekaar sowel as teenoor almal (beywer julle liewer altyd vir die belange van julle medegelowiges en van alle mense).

In die bekende 1 Tim 3:2 word gepraat van bekwaamheid "om te onderrig", van "regeer" (beheer) en van "sorgdra" vir die gemeente van God. Ook 1 Tim 5:17 praat van "regeer" (leiding gee). Aan die voorganger Timoteus self word ook opgedra om die Woord te verkondig, te weerlê, bestraf, vermaan in alle lankmoedigheid en lering (bemoedig deur met alle geduld onderrig te gee 2 Tim. 4:2). En hiervoor is die Woord van God juis so uitnemend geskik, dit is trouens deur God ingegee en is nuttig tot lering (het groot waarde om in die waarheid te onderrig), tot weerlegging (om dwaling te bestry), tot teregwysing (om verkeerdhede reg te stel), tot onderwysing in die geregtigheid (om 'n regte lewenswyse aan te kweek), sodat die mens van God volkome kan wees, vir elke goeie werk volkome toegerus (sodat die man wat in diens van God staan, volkome voorberei en toegerus sal wees vir elke goeie werk).

Titus 1: 7 bestempel 'n opsiener as 'n "rentmeester" van God (bestuurder van die huishouding van God). In vs 9 word hy beskryf as iemand wat vashou aan die betroubare woord waarin hy onderrig is sodat hy in staat kan wees om met die gesonde leer "te vermaan" (aan te moedig) en die teësprekers "te weerlê". In vs 13 word aan Titus gesê om 'n dwaalprofeet skerp "te bestraf" (streng teregwys) -iets wat Timoteus juis nié ten opsigte van bejaardes in die gemeentes moet doen nie! ( 1 Tim. $5: 1$ ).

In 1 Pet. $5: 2-3$ kry ons weer eens 'n samevatting van die ouderling se dienswerk: "Hou as herder toesig (oppas) oor die kudde van God wat onder julle is, nie uit dwang nie maar gewilliglik; nie om vuil (eie) gewin nie, maar uit bereidwilligheid (toegewydheid); ook nie as heersers (baasspelers) oor die erfdeel nie, maar as voorbeelde vir die kudde".

Uit hierdie talle omskrywinge is dit hopelik duidelik dat die pastorale taak (en metode) van die ouderlinge onmoontlik in een enkele formule vasgevang kan word. Elke eensydige benadering moet noodwending ' $n$ verarming teweegbring. Dit is ook totaal vreemd aan die pastoraat van Jesus Christus self by wie ons 'n ryke geskakeerdheid van pastorale aanpak aantref ${ }^{13}$. 
Die pastoraat van Christus as Opperherder dra tog die kenmerke van ${ }^{14}$ : uitnodiging (teenoor dwang); van selfontdekking (teenoor outoritivisme); situasie-gerigtheid (teenoor die kasuistiek van die Fariseërs met hulle 613 gebooie en verbooie); afwisselend individueelen dan weer massa-gerig; nederigheid; ontmoeting; diensvaardigheid; omvattendheid (na gees en liggaam); soekend. Kort saamgevat, waar die Fariseërs voortdurend op die mense gespioeneer het, daar het Christus voortdurend na hulle omgesien.

In die gereformeerde teologie word daar veel aandag geskenk aan die koningskap van Christus (Christus Kosmokrator) en miskien ook aan sy wederkoms en voleindigingswerk (Christus Konsummator). In die nuwe Teologie van die Rewolusie gaan dit veral oor die verlossing deur Christus (Christus Liberator). Maar Christus is veels te veelsydig om Hom net onder een aspek te benader. In die pastoraat moet ons veral 'n ope oog ontwikkel vir die vergete aspek van Christus as Trooster (Christus Konsolator) - en dan kom ons ook dig in die buurt van die Heilige Gees.

\subsection{Belydenisskrifte, Kerkorde, Formulier.}

Dit is opvallend dat hierdie veelsydigheid, hierdie méér-as-toesighouoor, ook in die Belydenis, Kerkorde en Formulier duidelik na vore kom.

Die NGB bevat geen uitgebreide verwysinge na die ampswerk van ouderlinge nie maar meld tog dat die Here deur hulle as opsieners, saam met die herders en diakens, die ware godsdiens onderhou en sorg dat die ware leer sy loop kan hê en dat oortreders op geestelike wyse gestraf en in toom gehou kan word (art. 30 ).

Artt. 16 en 23 van die Kerkorde verwys na hulle taak as die uitoefening van kerklike dissipline, en verder te sorg dat alles betaamlik en ordelik plaasvind (in die gemeente); ook toesig oor ampsdraers; huisbesoek doen tot stigting van die gemeente; lidmate vertroos en onderrig én om ook ander tot die Christelike godsdiens op te wek.

Die Formulier vir bevestiging van ouderlinge wys op die toesig hou oor die gemeente en predikant, raad en troos gee aan almal en die afweer van die wolwe.

\subsection{Bybelse pastorale motiewe.}

Ons kan ons onderwerp ook van 'n ander kant benader en kortliks let op die verskillende pastorale motiewe wat hier ter sprake kan kom. Ek lig 'n paar van die belangrikstes uit..15

2.4.1. Die Teo-logiese motief: God het die gemeente deur sy eie bloed verkry (Hand. $20: 28$ ) en Hy is innerlik bewoë oor (Jer. 31:20) en vol deernis en erbarming teenoor sy kudde (Matt. 9:35-38), en daarom gee Hy opdrag dat sy skape versorg en beskerm word. Die genade van God in Christus is die hárt van die pastoraat. ${ }^{16}$ En ons kan byvoeg: die lewe en werk van Christus (sy medelye! Luk $19: 41$ ) en die inwoning van die Heilige Gees. ${ }^{17}$

2.4.2. Die verkondigings (kerugmatiese) motief: Die evangelie is die blye boodskap wat moet deurgegee en toegepas word. Dit gaan om 
die kommunikering en konkretisering van die evangelie - kommunikasie dan korrek verstaan en nie in sy eensydige betekenis nie. ${ }^{18}$

2.4.3. Die onderrig- (didaktiese) motief (1 Tim. 3:2): Die lidmate moet onderrig word en weiding ontvang in die heilswaarhede en volle raad van God (Hand 20:27). Hulle moet geléér word om al die woorde van Christus te onderhou (Matt. 28:19b). Hulle moet geleer word dat om selfverloënend te dien sentraal staan in die Christelike lewe (Matt. 20:25-28, Mark 10:45, Joh. 13:14-15, Filip $2: 5 \mathrm{v})$.

2.4.4. Die opbou- (oikodomiese) motief: Dit gaan om die persoonlike (en gemeentelike) opbou in die geloof (Efes. 4:12). Daar moet by die gelowiges geloofsgroei en voortgang en diepgang in die lewe wees. Hulle moet geestelike volwassenheid en mondigheid bereik (Efes. $4: 13$ ), hulle moet kom tot die volle kennis van die wil van God (Kol. 1:9), hulle moet steeds toeneem in die genade en kennis van Jesus Christus ( 1 Pet. $3: 18$ ) en leer om van vaste spyse te lewe ( 1 Kor. $3: 2 \mathrm{v}$, Hebr. $6: 1$ ). In so 'n gesprek hoef dan uiteraard nie net oor geestelike dinge gepraat te word nie maar moet daar geestelik oor die dinge - álle dinge - gepraat word. ${ }^{10}$

2.4.5. Die gemeenskaps- (koinoniese) motief (Efes. 4:12). Dit gaan nie slegs oor persoonlike geloofsgroei nie maar daarmee saam ook oor die opbou van die gemeente van Jesus Christus. Koinonia is onmisbaar in die gemeente. ${ }^{20}$ Daar mag geen verdeeldheid in die liggaam van Christus wees nie maar die lede moet "gelyke sorg" vir mekaar dra (1 Kor $12: 25$; vgl. II Kor. 8:14). Die kudde vorm 'n onlosmaaklike eenheid.

2.4.6. Die bewarings- (poimainiese) motief (Joh. $21: 16$ ): Die kudde van Christus moet by die verkreë genade en die verworwe eenheid bewáár word (Joh. $21: 16$ ). Dit is nie die wil van die Vader dat "een van hierdie kleintjies verlore moet gaan nie" (Matt. 18:14; vgl. Joh. $6: 39,10: 28,18: 9$ ).

2.4.7. Die weerleggings- (polemies-apologetiese) motief: Uit bogenoemde vloei eintlik logies voort dat die wolwe (van buite en binne) uit die kudde geweer moet word en dat dwaalleer weerlê moet word (Tit. $1: 9,13,11$ Tim. $4: 2$ ).

2.4.8. Die Koninkryks- (basileiaanse) motief: Hierdie uiters belangrike motief is te lank in die pastoraat vergeet.21 Dit gaan in die pastoraat nie net oor die persoonlike geloofsgroei nie, ook nie net oor die gemeenskaplike gemeente-opbou nie, maar dit gaan bo alles om toerusting tot dienswerk in die Koninkryk van God. Die Koninkryk van God, wat in Christus en die Heilige Gees aangebreek het, beteken verlossing en vernuwing vir elkeen wat hom bekeer en glo. God het in Christus en deur sy Gees naby ons gekom en in ons kom woon, en al ons doen en late kom nou te staan binne die ruimte van Gods genadige heerskappy d.w.s. sy Koninkryk). Die goeie werke wat ons doen, vind nie net plaas binne die vier mure van 'n 
kerkgebou en binne die ruimte van die gemeente nie maar veral in die strate van die wêreld (Luk. $10: 36$, Rom. 12:17, Gal. 6:10, 1 Tess. $3: 12$, II Tim. $3: 17$, Tit. $3: 8$ ).

In die mooi Handleiding vir Ouderlinge, wat die Klassis Noordelike Pretoria onlangs uitgegee het, sal $\mathbf{u}$ opmerk hoe sterk kerksentries die enkele voorbeelde vir huisbesoek-gesprekke ingestel is ("kerkbesoek", huisgodsdiens, katkisasie, bydraes, nagmaalsvoorbereiding. Sondagheiliging). Ons sal moet leer om veel meer Koninkryksentries te dink en te doen, ook in ons pastoraat.

\subsection{Samevatting.}

Dit is duidelik dat ons met die begrip "toesig hou oor" slegs maar ' $n$ baie beperkte omskrywing kan gee van wat tydens huisbesoek gebeur en behoort te gebeur. Ons het uit die Skrif 'n hele aantal aspekte voorgehou: versorging, bewaring, ag gee, toerusting, vermaning, bemoediging, ondersteuning, onderrig gee, leiding gee (regeer), weerlegging, besturing, teregwysing ensovoorts. Veral die momente van opbou en bemoediging kom nie sterk na vore in ' $n$ eensydige pastoraat van toesig hou oor en berisping nie.

Ek pleit daarvoor dat ons wegbeweeg van 'n éénsydige na 'n mérsydige benadering. Daar is in die loop van die geskiedenis ' $n$ hele reeks pastorale modelle ontwerp en meeste van hulle gaan mank aan eensydighede. So is daar bv. die korrelasie-model van Tillich (gerig op persoonlikheidsgroei en selfhulp); die refleksie-model van Rodgers (non-direktiewe terapie tot selfhulp); die kerugmatiese model van Thurneysen (gerig op bekering); die noutetiese model van JE Adams (gerig op vermaning en konfrontasie); die opbou-model van Bolkestein (menslike hulp en gemeente-opbou); die parakletiese model van Firet (gerig op vermaning en vertroosting). ${ }^{22}$ Die Bybelse pastoraat is té veelsydig om dit in een model vas te vang. ${ }^{23}$

\section{HUISBESOEK IS MEER AS TOESIG OOR DIE LEER:}

\subsection{Leer en lewe.}

Daar is tereg in verband met die onderwerpverdeling onderskei tussen leer en lewe - die onderwerp oor die toesig oor die lewe is trouens deur iemand anders behandel. Dit is haas onnodig om op te merk dat ons hier egter nooit mag skei nie. In die prediking van die profete, van Christus en van die apostels loop die lyne van leer en lewe, belydenis en belewenis, dogmatiek en etiek dikwels deurmekaar. Soms gaan die leer voorop en volg die etiese voorskrifte daarna, soos in talle van die briewe van die apostel Paulus. Soms gaan die lewe voorop (Filip $2: 1-5$ ) en volg die leer (Filip $2: 6-11$ ). Soms lê die twee so ineengestrengel dat hulle moeilik ontwar kan word, soos bv. in Gal. 2 waar Paulus vir Petrus in die openbaar vermaan omdat hy die eenheid van die gemeente verbreek deur te weier om saam met sekere broeders (Christene uit die heidendom) nagmaal te vier.

\subsection{Ou en nuwe probleemvelde.}

Binne die ruimte van die GKSA is daar tradisioneel 'n aantal etiese vraagstukke wat wyd verspreid voorkom en waaroor nasionale sino- 
des ook al (soms goeie en soms minder goeie) besluite geneem het. Interessant was die bestaan (en vergaan in 1967) van 'n deputategroep wat spesifiek op hierdie terrein beweeg het en bekend was as die deputate vir "sosiale euwels". So 'n vinnige blik in wat ons "sinodale etiek" sou kon noem, lewer interessante gegewens op en verdien eintlik 'n diepgaande studie. Ek noem 'n paar van die sake waaroor besluite geneem is.

In verband met die seksuele etiek is oa. die volgende besluit:

- teen (kleur-) gemengde huwelike $(1891,1920,1939)$, en dan weer dat dit in beginsel mág $(1970,1976,1979)$.

- teen onbetaamlike kleredrag (oa. 1924).

- teen huwelike met die weduwee van 'n oorlede broer (1894, 1897) en weer daarvoor (1949).

- teen dans $(1927,1955)$.

- teen egskeiding en hertroue $(1924,1936,1964)$.

- teen kinderbeperking $(1933,1936,1982)$.

- teen gemengde baaiery (1945).

- teen die adverteer van vroue-onderklere in winkelvensters (1952)

- (indirek) ten gunste van voorbehoedmiddels (1973, vgl. 1970).

- (indirek) teen homofilie (1976).

- teen pornografiese lektuur (1958 en telkens weer).

- teen die saamwoon van ongetroudes (1961).

- die sinode weier om hom uit te spreek teen kunsmatige inseminasie by diere $(1952,1964)$ en mense (1964).

- teen die dubbelslagtigheid van die Ontugwet (1982; vgl. 1979).

'n Paar voorbeelde uit die politieke etiek:

- vir 'n rebellie (1916).

- teen vrouestemreg in politiek (en kerk) (1920).

- teen bewapening van nieblankes in die weermag (1942)

- (indirek) teen 'n atoomoorlog (1961).

- teen (die nadelige gevolge van) trekarbeid (1976).

- vir militêre diensplig (1982).

- teen rassisme (1967) maar vir apartheid (1970).

Voorbeelde uit die kansetiek:

- teen kaartspel $(1933,1936)$.

- teen lotery en dobbelary (1936, 1939 en telkens weer)

- teen bonusobligasies (1979).

Enkele ander sake:

- teen drankmisbruik maar vir regte gebruik (1924 en herhaaldelik).

- teen Sabbatsontheiliging (herhaaldelik).

- teen selfmoord (1936).

- teen lykverbranding $(1933,1945,1952)$.

In hierdie gevalle beskik die ouderlinge dus min of meer oor 'n leidraad om hulle in hulle pastorale gesprek oor etiese vraagstukke te help - hoewel sommige van hierdie besluite reeds agterhaal en nie meer relevant is nie (vgl. bv. vrouestemreg in die politiek, bewape- 
ning van nieblankes in die weermag ens). Maar hoe moet hy maak met moderne etiese vraagstukke waaroor nog geen sinode besin - of selfs gedink - het nie?

Wat moet hy antwoord indien ' $n$ kinderlose en infertile egpaar aan hom meedeel dat hulle van 'n ekstreme proefbuisbaba-tegniek (buite die manlike sperma en die vroulike eiersel om) gaan gebruik maak? Hoe moet hy reageer as iemand sy hele liggaam vir nadoodse eksperimentering bemaak? Watter leiding moet hy gee ten opsigte van sake soos aborsie, eutanasie, militêre diensweiering, boks, reënmaak/wolketap, ewolusie, gesinsbeplanning, omgewingsbesoedeling, energiebronnebesparing ens? Die moderne samelewing is so oorspoel met byna onoplosbare etiese vraagstukke dat dit met 'n etiese grondverskuiwing en rotsstorting vergelyk kan word. Wat gaan hy sê as 'n kankerpasiënt hom meedeel dat hy en sy dokter tot "invriesing" besluit het sodat hy weer oor tien of honderd jaar "ontvries" kan word wanneer 'n toepaslike geneesmiddel uitgevind is? En hoor ons nie al daarvan dat babas by supermarkte gekoop sal kan word met die keuse van oë en hare daarmee saam nie? Hoe moet die ouderling as herder toesig hou oor en leiding gee aan lidmate ten opsigte van vraagstukke waarvan hy die antwoorde nie weet nie?

Wanneer op alle vrae 'n kitsklaar antwoord gegee sou kon word, is ons natuurlik weer terug by die ou legalistiese Fariseīstiese kasuïstiek met sy reël-op-reël en gebod-op-gebod standpunt. Maar so 'n benadering verskil hemelsbreed van die Christelike.

Ek gaan probeer om vervolgens enkele ringtingwysers aan te dui wat moontlik vir die ouderlinge tot hulp kan wees in hulle pastorale sorg oor die lewe van die gelowiges. Ek veronderstel hier dat 'n ouderling oor 'n goeie kennis van die Woord, van sy medemens en van homself beskik ${ }^{24}$ en dat hy geestelik en metodologies goed toegerus is, dat hy waarlik kan kommunikeer en dat hy die gelowiges met deernis en begrip benader.

\subsection{Pastoraal-etiese rigtingwysers.}

3.3.1. Onderskei tussen sonde en sondaar: Uit die pastorale benadering van Christus blyk baie duidelik dat Hy baie skerp onderskei het tussen sonde en sondaar (vgl. ook II Tess. $3: 14-15){ }^{25}$ (Ook Calvyn hanteer nou hierdie onderskeiding, Institusie III $4: 34$, IV 12 : 10 - waarna ek nou telkens in die teks gaan verwys). In sy ontmoeting met die owerspelige vrou (Joh. 8 - weliswaar tekskrities onseker) en met Saggeus (Luk. 19) sien ons hoedat Christus die sonde afkeur maar Hom vol erbarming tot die sondaar wend. Hy het Hom selfs in nederigheid en selfontlediging só tot die mens gewend dat $\mathrm{Hy}$ saam met sondaars geëet en by hulle tuisgegaan het (Luk. 15:2, 19:7), met vrouens in die openbaar gepraat het, wat ongehoord was (Joh. 4:9), en sodoende die verwyt op die hals gehaal het dat Hy 'n vraat en 'n wynsuiper is en 'n vriend van tollenaars en sondaars genoem is (Luk. $7: 34$ ). 
Die sonde moet duidelik afgewys word maar die sondaar bly voorwerp van gesprek en bearbeiding - tensy ons met 'n geïnkarneerde duiwel te doen kry!

Het ons ouderlinge byvoorbeeld enige begrip van hoe 'n homoseksuele man of vrou (waarvan daar waarskynlik 5\%, dws tien groot gemeentes in die Gereformeerde kerkverband is) pastoraal begelei behoort te word? Weet ons om te onderskei tussen homoseksuele aard (iemand wat 'n homoseksuele geaardheid het) en homeseksuele daad (iemand wat 'n homoseksuele praktyk beoefen. ${ }^{25}$ En hoe begelei ons 'n ongetroude verwagtende jongmeisie?

3.3.2. Onderskei tussen sonde en sede: Daar is sekere oortredinge waaroor 'n ouderling nie die minste hoef te twyfel nie: onsedelikheid, onreinheid, losbandigheid, afgodediens, towery, vyandskap, naywer, woede, rusie, verdeeldheid, skeuring, afguns, dronkenskap, uitspattigheid ens. (Gal. 5 : 19-21; vgl ook II Kor. 12:20; Efes $4: 31,5: 5-6$; Kol. 3:8; Tit. 3:3; 1 Kor. 6:9-10; 1 Pet. 2:1). Maar daar is ander dinge wat nie heeltemal so duidelik as oortreding van die Wet aangemerk kan word nie. Is gemengde baaiery sonde? Is fietsry op 'n Sondag sonde. Is die dra van lang hare sonde? Is die dra van kort tennisbroeke by mans sonde? (Daar was dae toe op die PUK massavergaderings teen laasgenoemde gehou is!)

Elke ouderling moet in die pastoraat met hierdie onderskeiding deeglik rekening hou. En hy moet ook dáármee rekening hou dat sy eventuele teregwysing hier duidelik uit die Woord van God kom. As hy bloot moet terugval op sy persoonlike opinie, kerklike tradisie of sinodale besluit, sonder Skrifmotivering, sal sy vermaning die nodige $\mathrm{krag}$ mis. In die Gereformeerde Kerke ken ons ook geen sinodokrasie of sinodalisme nie maar alleen teokrasie: God alleen regeer deur sy Woord en Gees. Uiteraard sal 'n ouderling alleen dan vrymoedig uit die Woord kan vermaan as 'n bepaalde sonde ondubbelsinnig deur die Woord weerspreek word.

3.3.3. Onderskei tussen oorsaak en simptoom (wortel en vrug): By talle van die etiese vraagstukke wat in die pastoraat na vore kom, sal veel dieper as die uiterlike simptoom gedelf moet word. Daar moet deurgedring word tot die diepste oorsaak wat niks anders kan wees nie as die verhouding van die mens tot God. Indien hierdie verhouding versteur is, loop talle dinge verkeerd. Pastoraal gesien is dit volkome vrugteloos om aan die kwade vrug te dokter terwyl die aangetaste wortels onaangeraak bly (vgl. Spr. 4:23), Mark 7:15, 21-23).

3.3.4. Onderskei tussen misdaad en misstap: Alhoewel die Gereformeerde teologie nie die Roomse onderskeiding van doodsonde en vergeeflike sonde ken nie, het ons tog altyd aanvaar dat daar gradasie in die sonde is (vgl. Matt. 11:22; Luk. 12:48). In navolging van Calvyn (vgl. ook KO art. 85) het ons onderskei tussen middelmatige en fundamentele dinge (III 19:7, 13; IV 10:4) en ek meen dat hierdie onderskeiding met vrug in die pastoraat gebruik kan word. Calvyn praat bv. van "bose misdade" en "ligtere vergrype" (IV $12: 4$, 
6; vgl. III $4: 14$ ). Natuurlik, groot of klein sonde, dit bly nog sonde; groot of klein oortreding, dit bly nog oortreding. Tog meen ek daar is ' $n$ verskil in soortlike gewig tussen ' $n$ oortreding waar iemand bv $110 \mathrm{~km}$. per uur ry (ipv. die toelaatbare 100) én waar iemand doelbewus ' $n$ moord pleeg, tussen die eet van toonbrode in 'n noodsituasie (Luk. $6: 3-4$ ) en owerspel met sy naaste se vrou. Is 'n ouderling wat 'n verkeersboete vir 'n ligte oortreding gekry het bv. tugwaardig in terme van art. $79 \mathrm{KO}$ ?

In die pastoraat mag ons nie sondes vergoelik nie, maar ons mag ook nie van 'n molshoop ' $n$ berg maak nie. Ons moet onderskei tussen misdaad en misstap. Ons Kerkorde praat ook telkens van "growwe" sondes (artt 76, 79, 80). Hierdie onderskeiding beinvloed ons pastorale metode en aanpak ${ }^{26}$.

3.3.5. Onderskei tussen doelbewuste en onbewuste oortreding: Hierdie onderskeiding kom ook in die Heilige Skrif voor. Die invloed van die sonde is so verstrekkend en so radikaal dat dit inderdaad moontlik is om ook onbewustelik te sondig (Luk. $12: 48$, Hand. 3:17; 1 Tim. $1: 13$; Hebr. $5: 2 ; 1$ Pet. $1: 14$ ). Dit sal vir die afgeleë Tirus en Sidon verdraagliker wees in die oordeelsdag as vir Kapernaum, Gorasin en Betsaida, wat Christus in aksie gesien en gehoor het en tog nie geglo het nie (Matt. $11: 20-24$ ). Die pastorale wenk is: "Hy wat nie geweet het nie en dinge gedoen het wat straf verdien, sal 'n ligte straf kry" (Luk. 12:48).

Hou in die pastoraat dus daarmee rekening of 'n lidmaat welbewus sondig en of hy hom onbewus in 'n gevaarsituasie ingelaat het. Die Skrif sê dat vir 'n doelbewuste en opsetlike sondaar min hoop is (Hebr. 6:4-6, 10:26). Iemand wat onbewus en te goedertrou bonusobligasies uitgeneem het, moet anders benader word as hy wat dit doelbewus en uitdagend gedoen het.

3.3.6. Onderskei tussen volhardende en eenmalige oortreding: Hierdie onderskeiding hang nou saam met die vorige en kom ook in ons Kerkorde ter sprake waar o.a. van "hardnekkigheid" (art. 76) en van "gewoontedronkenskap" sprake is (art. 80). Ook hierdie onderskeiding is volkome Skriftuurlik, want dit maak 'n groot verskil of iemand eenmalig in ' $n$ oomblik van swakheid geval het en of hy welbewus op 'n verkeerde ingeslane weg volhard. Hiermee kom ons selfs in die omgewing van die sonde teen die Heilige Gees (Matt. $12: 31: 32$ ) - hoewel hier 'n derde element bygevoeg moet word $\mathrm{nl}$. Christus se vernuwingswerk as duiwelswerk af te skryf.

"Laat ons tog nie 'n mens veroordeel omdat hy eenmaal geval het nie, aangesien selfs die allerheiligstes soms ook swaar sondig" (Institusie IV $1: 16$ ).

In die geval van 'n eenmalige oortreding sal die ouderling waarskynlik ook makliker daarin slaag om die lidmaat tot skuldbelydenis en berou te lei as wanneer daar verbete volharding ingetree het. 'n Alkoholis vra om 'n ander benadering as die lidmaat wat eenmalig drank misbruik het. 'n Jongmens wat elke naweek in 'n obskure diskoteek rondlê, moet anders benader word as hy wat een maal aan 'n matriekdans deelgeneem het. 
3.3.7. Onderskei tussen openbare en verborge oortreding: Daar is voorbeelde in die Skrif waar iemand oop en bloot in die openbaar oortree het, bv. Petrus in Antiochië, en dat Paulus hom openlik voor die gemeente weerspreek het (Gal. 2:11; vgl. 1 Tim. 5:20). Ons Kerkorde volg die Skrif hierin na (art. 72-76) (vgl. ook Institusie IV $12: 3$ ). As my broeder (teen my of iemand anders) sondig, moet ek sy sonde nie aan die groot klok hang en dit met ánder bespreek nie, nee, ek moet met hóm alleen praat (Matt. 18:15; vgl. Matt. $5: 23-24)$. Ek moet "my naaste se eer en goeie naam na my vermoë verdedig en bevorder (HK $43: 112$ ).

Dit sal dus onwys, en verkeerd, wees vir 'n ouderling om met elke sondegeval na die kerkraad te gaan. As 'n suster vertroulik aan hom genoem het dat haar man 'n verhouding met 'n ander vrou het, moet die ouderling eers probeer om - indien enigsins moontlik - die mán onder vier oë te spreek.

3.3.8. Waak teen ' $n$ eensydige benadering: Daar sal situasies wees waar die ouderling, anders as Eli (1 Sam. 3:13), soms streng moet bestraf en skerp moet vermaan (vgl. Titus $1: 13$ ). Soos Natan vir Dawid (II Sam. 12:7 - watter pragtige stukkie pastoraat vind ons hier!) of soos Christus vir die skrifgeleerdes en Fariseërs (Matt. 23). Soms sal dit juis nié die geval wees nie, soos Jesus teenoor die owerspelige vrou (Joh. 8:11) en soos Paulus aanbeveel dat daar nié met die ouer mans gehandel moet word nie (I Tim. 5:1) (vgl. Institusie IV, $12: 8$ ).

3.3.9. Waak teen selektiewe moraal: Ons het in ons kerklike lewe en pastoraat begin selekteer tussen die oortredinge. Veral die oortredinge van die vierde en sewende gebod oor Sondagsheiliging en die huweliksetiek is uitgelig. Hoeveel keer praat ons met iemand en meld dit uiteindelik by die kerkraad aan - wat aanhoudend laster, wat lieg en steel, wat sy medemens mishandel, wat hom beswadder (juis in die politieke klimaat vandag), wat weier om saam met 'n medebroeder te aanbid of nagmaal te vier? As u 'n Gereformeerde lidmaat tydens 'n politieke vergadering eiers sien gooi na die spreker, sal u hom daaroor aanspreek of nie?

3.3.10. Waak teen kasuïstiek: Ouderlinge moet daarteen waak om op spitsvondige wyse vir elke probleem 'n oplossing te probeer aanbied. ${ }^{27}$ Sekere etiese probleme kom nie direk in die Skrif voor nie sodat 'n lynregte konklusie nie altyd moontlik is nie. Elke geval moet op meriete oorweeg word. Elke situasie het sy eie unieke (versagtende of verhardende) omstandighede. Christus tree anders op teenoor die verharde Fariseërs as teenoor die berouvolle sondaar (vgl. Luk 18:13-14). Paulus oordeel dat besnydenis in die een geval korrek is (Hand 16:3) en in die ander nié (Gal 2:3). Dit hang af of die kalf in die put is (Luk 14:5) en of die Wet uit nood dan wel uit blinde verset oortree word (Luk 6:45). Dikwels sal die ouderling saam met die lidmaat en saam met die predikant en soms ook saam met ander deskundiges) moet worstel om op 'n moeilike vraag die regte antwoord te kry. 
3.3.11. Waak teen ' $n$ eensydige metode: $\mathrm{Ek}$ het in bogenoemde die klem laat val op die "toesig hou oor", maar ek herinner weer daaraan dat daar ook ánder en méér pastorale aspekte aanwesig moet wees. Die aspek van opbou en toerusting van die gelowiges is van wesentlike betekenis. ${ }^{28}$ Hier sal die aksent val op sake soos: liefde, vreugde, vrede, geduld, vriendelikheid, goedhartigheid, getrouheid, nederigheid en selfbeheersing (Gal. $5: 22$ ). Saamgevat: op geloof, hoop en liefde ( 1 Kor. $13: 13$ ).

Uiters belangrik is myns insiens ook die (voorwaardelike) vryspraak in die naam van Christus (vgl. Institusie IV 19:14). Wanneer iemand oortree het en opregte berou uitgespreek en betoon het (Jak. 5:16), dan geld ook vir hom die woorde van 1 Joh. $1: 9$ : "Maar as ons ons sondes bely - $\mathrm{Hy}$ is getrou en regverdig, Hy vergewe ons ons sondes en reinig ons van alle ongeregtigheid" (vgl. Matt 18:18, Joh. 20:23; HK 31:85). En wat is heerliker as die vryspraak in Christus; Is bekering en vergewing dan nie die kern van die evangelie nie (Luk 24:47)? En wanneer ware berou ingetree het, is die persoonlike en kerklike vermaning afgeloop (Institusie IV12:8). Mens slaan tog nie 'n hond wat lê nie! Ons Belydenis bepaal dat 'n afgesnedene weer as lid van Christus en van sy gemeente aangeneem word wanneer hy waaragtige verbetering beloof en bewys (HK 31 : 85).

Ek wys hier ook net daarop dat hier veral aandag gegee is aan die pastoraat van die ouderling ten opsigte van kerklidmate. 'n Ander baie belangrike aspek van sy taak is ook om sending te doen, of soos die Kerkorde dit stel: "ook ander tot die Christelike Godsdiens op te wek" (art. 23). In verband hiermee vind ons pragtige materiaal in die bekende gelykenis van die verlorene in Luk. 15.

Sommige pastorale teoloë verval egter hier in 'n verwarrende eensydigheid deur nie tussen gelowiges en ongelowiges te onderskei nie maar bloot van "mense" te praat. ${ }^{29}$ Dit is waar dat die ouderling in hierdie verband baie kan leer van die sg. evangelistiek, van sy metodes, van die verskillende menstipes ${ }^{30}$, maar tog bly daar 'n groot onderskeid tussen dic versorging en bewaring van gelowiges en die evangelisering van ongelowiges. Hierdie onderskeid mag ons nie vergeet nie.

Ek sluit af deur baie kort op 'n laaste saak te wys.

\section{DAAR IS MEER TOESIG AS NET TYDENS HUISBESOEK:}

Ons het die aandag veral gefokus op huisbesoek. Maar dit is nie die enigste plek waar ouderling en lidmaat ontmoet nie. Hulle ontmoet ook by die werk, op die sportveld, by die politieke en kulturele byeenkomste ens. Nêrens is die ouderling van sy pastorale roeping onthef nie. In woord en daad, in voorbeeld en gesprek, oral en altyd bly hy herder, al is dit op 'n gevarieerde wyse. Dit is selfs begryplik dat in 'n moderne mobiele samelewing daar gewerk word aan 'n beroepspastoraat, aan industrie-pastoraat, weermag-pastoraat ens, en wel nie ter vervanging van die huispastoraat nie maar ter aanvulling daarvan, nie kompeterend nie maar komplimenterend. 
Gesien die hoë egskeidingsyfer vandag in die RSA meen ek dat besondere aandag aan huwelikspastoraat gegee behoort te word.

\section{OM AF TE SLUIT.}

Ek is maar te deeglik bewus dat hierdie voordrag dalk meer vrae by u opgeroep het as wat dit antwoorde verstrek het. Nietemin hoop ek dat die paar wegwysers wat aangedui is aan u 'n helpende hand sal gee. Dit is ook die waarde van 'n konferensie (soos hierdie) want alleen "saam met al die heiliges" kan ons die liefde van Christus ken (Efes. 3:18). Eers saam met die ouderlinge en die hele gemeente van Jerusalem het die apostels 'n besluit oor die afskaffing van die OT besnydenis geneem - natuurlik onder leiding van die Heilige Gees! (Hand 15).

Die waarheid word sáám ontdek en nie individualisties ontwerp nie. ' $n$ Kernvraag in die pastoraat is: Herken die lidmaat in my as herder die gestalte van Jesus Christus? In my vermaning en opbouing, bewaring en versorging van die kudde gaan dit wesentlik nie om "my" nie maar om die teenwoordigstelling en vergestalting van Christus self (Joh. $3: 30$ ). Indien ek hierin slaag, is my pastoraat geslaagd. Maar as die lidmate Christus hoegenaamd nie in my herken nie en ek hulle uit die hoogte met grootdoenerigheid en belang. rikheid tiranniseer, dan is my pastoraat 'n volkome mislukking.

Voordrag tydens 'n byeenkoms van ouderlinge te Witbank 1982.

\section{VOETNO'IAS:}

1. Vgl. Jansen van Vuuren du Plessis 1980. Die Skriftuurlike Grondslag van die kerklike pastoraat vanuit 'n eksegetiese en prinsipieel leerstellige siening met 'n verwysing na die problematiek van die Pastorale Psigologie. Bloemfontein (UOVS, proefskrif), 425-438.

2. Vgl. Venter C. J. H. Junie 1982. Egskeiding as pastorale probleem met besondere verwysing na die nuwe egskeidingswetgewing. In die Skriflig, 16 (62) : 12v; Heitink, G. 1977. Pastoraat als hulpverlening: Inleiding in de Pastorale Theologie en Psychologie. Kampen: J. H. Kok, 184. Kyk ook Venter, C. J. H. 1973. Huisbesoek: Prinsipieel en Prakties besien. Die Goue Kandelaar. Potchefstroom (33-36).

3. Van der Walt, J. J. 1978. Metode in die pastoraat. Potchefstroom: PU vir CHO, 9.

4. Vgl. De Klerk, W. J. 1959 (2). Die Herder-ouderling. Potchefstroom: Pro Rege, 16; De Klerk, W. J. 1964. Wending?: Vernuwingsgesprekke oor die Gereformeerde Kerkpraktyk Potchefstroom: Pro Rege, 88v; Heitink aw 162. Vgl. ook De Klerk, W. J. 1975. Pastorale Sensitiwiteit. Johannesburg: Perskor.

5. Heitink aw $135 \mathrm{v}, 181$; vgl. 75 .

6. Wurth, G. B. 1955. Christelijke Zielzorg in het licht der moderne Psychologie. Kampen: J. H. Kok NV. 
7. Louw, D. J. 1982. Pastoraat en lyding. Kaapstad: NG Kerk-Uitg, 17.

8. Dijk, K. 1952. De Dienst der Kerk. Kampen: J. H. Kok KV, 162. Vgl. ook Dijk, K. (red). 1952. Handboek voor de Ouderling. Delft: Uitg Van Keulen.

9. J. J. van der Walt aw. 3 .

10. Heitink aw $289 \mathrm{v}$.

11. Louw 1982 aw $19 \mathrm{v}$.

12. Vgl. Jansen van Vuuren du Plessis aw 36-218.

13. Wurth, Christelijke Zielzorg aw 23.

14. Vgl. De Klerk, J. J. 1978. Herderkunde. Pretoria: NG Kerk-boekhandel, 3v.

15. Vgl. Lnuw, D. J. 1980. Op soek na die huisgenote van die geloof: Riglyne vir Huisbesoek. Pretoria: NG Kerk-boekhandel, 6-10; Jansen van Vuuren du Plessis aw 390_414; Müller, BA. 1981. Skrifgebruik in die pastoraat. Kaapstad: NG Kerk-Uitg.

16. Wurth, Christelijke Zielzorg aw 22.

17. Louw 1982 aw $16-18$.

18. Van Andel, G. (z j, 7e druk). Vanavond komen de ouderlingen. (In Kerkelijk Meeleven. Rotterdam: J. H. Donner, 27).

19. Soos by Heitink aw 182, 188. Vgl. Jonker, W. D. 1976. Die Woord as Opdrag: Gedagtes oor die prediking. Pretoria: NG Kerk-boekhandel, 79v.

20. Heitink aw 183v; Wurth, Christelijke Zielzorg aw 122v.

21. Vgl. Heitink aw 159-161 en veral Jansen van Vuuren du Plessis aw $239-265$.

22. Louw 1982 aw 8-15; J. J. de Klerk, Herderkunde aw 31v; Firet, J. 1977 (3). Het agogisch moment in het pastoraal optreden. Kampen: J. H. Kok.

23. Vir 'n Bybelse fundering van die pastoraat, vgl. J. J. de Klerk, Herderkunde aw 104-116; Motze, G. J. 1971. Die antropologiese onderbou van die Gereformeerde Pastoraat met spesiale verwysing na die Clientcentered Amerikaanse Pastoraat. Potchefstroom (proefskrif); BA Müller aw 26v.

24. Vgl. J. J. de Klerk, Herderkunde aw hfstt 4-5; Venter, D. G. ea. 1956 (2). Handeling vir Ouderlinge. Potchefstroom: Pro Rege; Spoelstra, B. Mrt. 1976. Die diens van die ouderling vandag. In die Skriflig, 9 (36) : 41-48.

25. Wurth, Christelijke Zielzorg aw 24v. Kyk ook Wurth, GB. 1957 (2). Het Christelijk Leven: Grondlijnen der Ethiek. Kampen: J. H. Kok NV, 256. Vgl. Benoit, J. D. Oorspr 1947. Calvijn als Zielzorger. Nijkerk: GF Callenbach NV (vert). 25.1 Vgl. Botha, A. 1980. Pastorale Sorg aan die Homoseksueel: 'n Handleiding aan Pastorale versorgers. Bloemfontein: NG kerk Jeugboekhandel; en Louw, D. J. 1980 in: Perspektiewe op Homoseksualiteit. Durbanville: Uitg Boschendal (93-139).

26. Vgl. Douma, J. 1980. Verantwoord Handelen. Inleiding in de christelijke ethiek. Amsterdam: Uitg Ton Bolland, 91, 94 (ivm die prostituut wat haar familie aan die lewe hou).

27. Vgl, Wurth, Christelijke Zielzorg aw 26v.

28. Vgl. Ridderbos, H. 1966. Paulus: Ontwerp van zijn theologie. Kampen: Uitg J. H. Kok NV, 510-513.

29. Heitink aw 75, 188, 289.

30. Vgl. Overduin, J. 1958. Tact en Contaci: De moderne mens en het evangelie. Kampen: J. H. Kok NV. 